\title{
MODEL ADVOKASI LSM JKPS CAHAYA TERHADAP BURUH MIGRAN ASAL KABUPATEN PONOROGO
}

\author{
Robby Darwis Nasution \\ Fakultas Ilmu Sosial dan Ilmu Politik, Universitas Muhammadiyah Ponorogo \\ Jalan Budi Utomo Nomor 10, Kabupaten Ponorogo, Kode Pos 63471 \\ darwisnasution69@gmail.com
}

\begin{abstract}
The high number of Indonesian Workers ultimately affects the high problems arising from the flow of these migrant workers. The handling of cases conducted by the government sometimes bumps with the bureaucracy to make the handling becomes slow, so that emerged many non-governmental organizations (NGOs) engaged in the field of assistance and protection of migrant workers. Therefore it is very interesting to see more about the pattern of assistance done by this NGO. This research uses qualitative descriptive method using field data as primary source and reference / literature as secondary source. The conclusion of this research is that the advocacy pattern conducted by NGO JKPS CAHAYA in the form of "tiered mentoring" with personal approach proved more effective when compared with the pattern of advocacy done by government with institutional bureaucratic model.
\end{abstract}

Keyword: non-governmental organizations (NGOs), Adcocacy, Indonesian Workers

\begin{abstract}
Abstrak
Tingginya jumlah Tenaga Kerja Indonesia (TKI) pada akhirnya berdampak kepada tingginya permasalahan yang timbul karena arus buruh migran ini. Penanganan kasus yang dilakukan oleh pemerintah terkadang terbentur dengan birokrasi hingga membuat penanganan menjadi lambat, sehingga muncullah banyak Lembaga Swadaya Masyarakat (LSM) yang bergerak dalam bidang pendampingan dan perlindungan TKI. Maka dari itu sangat menarik sekali jika melihat lebih jauh tentang pola pendampingan yang dilakukan oleh LSM ini. Penelitian ini menggunakan metode deskriptif kualitatif dengan menggunakan data dilapangan sebagai sumber primer dan referensilliteratur sebagai sumber sekunder. Kesimpulan yang dihasilkan dalam penelitian ini adalah pola advokasi yang dilakukan oleh LSM JKPS CAHAYA yang berupa "pendampingan berjenjang" dengan pendekatan personal terbukti lebih efektif jika dibandingkan dengan pola advokasi yang dilakukan oleh pemerintah dengan model birokrasi institusinya.
\end{abstract}

Kata Kunci : Lembaga Swadaya Masyarakat(LSM), Advokasi, Tenaga Kerja Indonesia (TKI)

\section{A. Pendahuluan}

1. Latar Belakang Permasalahan

Penempatan tenaga kerja Indonesia (TKI) ke luar negeri merupakan kebijakan nasional yang bertujuan untuk meningkatkan kesejahteraan sosial ekonomi khususnya terhadap tenaga kerja dan keluarga TKI. Karena keterbatasan pemerintah dan sektor swasta dalam menyediakan lapangan pekerjaan, maka tingkat pengangguran di
Indonesia terus meningkat dan kenaikan jumlah TKI keluar negeri juga terus meningkat. Di Kabupaten Ponorogo sendiri tercatat oleh Dinas Sosial Tenaga Kerja dan Transmigrasi (DINSOSNAKERTRANS) pada tahun 2014 penduduk Ponorogo yang menjadi TKI keluar negeri sejumlah 4039 orang dengan tujuan terbesar di negara Hongkong dan Taiwan. Jumlah ini tentu tergolong fantastis jika dilihat Ponorogo 
merupakan kota yang kecil sehingga pantas kalau dikatakan bahwa Ponorogo merupakan salah satu kota penyumbang TKI terbesar di wilayah Jawa Timur.

Besarnya jumlah TKI asal ponorogo ini selain meningkatkan taraf hidup bagi masyarakat, ternyata juga menyisakan banyak permasalahan baik terkait dengan keluarga yang ditinggalkan ataupun dengan pemerintah negara tujuan seperti contoh beberapa waktu lalu dikabarkan TKI dari Kabupaten Ponorogo dilaporkan meninggal akibat menghirup gas beracun di sekitar apartemen yang merupakan tempatnya bekerja di Makau. (Sujarwoko, 2012) Selain kasus kekerasan yang sering terjadi pada TKI di luar negeri, juga terjadi permasalahan serius yang menimpa banyak TKI Ponorogo yaitu kasus perceraian yang secara tidak langsung berdampak kepada ekonomi keluarga ataupun psikologis anak yang ditinggalkan.

Menurut data yang dihimpun oleh Crisis Center PUSLITFO BNP2TKI, jumlah pengaduan maslah TKI yang sering terjadi cukup tinggi dimana jumlah total pelaporan yang masuk ke crisis center yang berjumlah total 4.894 pada tahun 2015. (BNP2TKI, 2015) Angka ini tergolong cukup tinggi dengan melihat jumlah TKI yang berada di luar negeri yang berada di seluruh negara tujuan TKI.

Terbitnya UU tentang perlindungan TKI tentu membawa angin ketenangan bagi TKI yang berada di luar negeri, tetapi kalau kita lihat kasus Ruyati asal Bekasi pada 18 Juni 2011 yang dieksekusi mati di Arab Saudi berselang dua hari setelah Organisasi Buruh Internasional (ILO) adalah bukti nyata kegagalan Pemerintah Indonesia dalam membela dan melindungi warga negaranya. Banyaknya permasalahan yang dialami oleh TKI kita di luar negeri memberikan gambaran betapa perlindungan hukum yang diberikan kepada TKI masih jauh dari harapan, meskipun telah ada perangkat hukum nasional maupun internasional yang dapat digunakan untuk memberikan perlindungan hukum kepada TKI yang bekerja di luar negeri yaitu Undang-Undang Nomor 39
Tahun 2004 tentang Penempatan dan Perlindungan Tenaga Kerja Indonesia di Luar Negeri.

Hal yang mendasar dari kegagalan pemerintah ini adalah lambatnya respon karena prosedur yang panjang serta lemahnya kontrol terhadap TKI di luar negeri. (Hidayah, 2011) Lambatnya respon pemerintah ini selanjutnya ditanggapi oleh Lembaga Swadaya Masyarakat yang bergerak di bidang perlindungan TKI untuk ikut andil dalam memberikan advokasi kepada buruh migran beserta keluarganya sehingga bisa menyelesaikan permasalahan yang dialami. Salah satu LSM yang bergerak dalam advokasi TKI yaitu JKPS Cahaya yang memperjuangkan hak-hak TKI benama Anis Andriani asal Desa Bajang, Kecamatan Mlarak, Kabupaten Ponorogo yang dipotong jari tangan kirinya oleh majikannya di Hongkong. (Sudarmawan, 2014) maka dari itu sangat menarik sekali jika dalam penelitian ini melihat lebih jauh bagaimana model advokasi yang dilakukan oleh LSM dan seberapa efektif adokasi yang dilakukan.

\section{Kerangka Teori}

Konsep perlindungan Tenaga Kerja Indonesia (TKI) banyak peneliti beranggapan bahwa perlindunga TKI merupakan tanggungjawab pemerintah sebagai pemangku kekuasaaan dalam Negara. Dasar penegakan perlindungan terhadap TKI ini berlandaskan kepada Undang-Undang Republik Indonesia Nomor 39 Tahun 2004 tentang Penempatan dan Perlindungan Tenaga Kerja Indonesia di Luar Negeri. (RI, 2004) Didalam Undang-Undang Tersebut jelas disebutkan bahwa Pemerintah memiliki tanggungjawab terhadap perlindungan TKI baik pasca, saat di negara tujuan maupun purna/kepulangan. Selain itu, dalam Peraturan Daerah Propinsi Jawa Timur Nomor 2 Tahun 2004 lebih menegaskan apa yang sudah ada di UU Nomor 39 tahun 2004 dimana dalam Peraturan Daerah Provinsi ini menjabarkan perlindungan yang terkait dengan pendaftaran asuransi oleh PPTKIS dan Pemeriksaan kesehatan saat keberangkatan dan kepulangan. (JATIM, 
2004)

Keberadaan LSM sebagai bagian dari civil society membuktikan adanya pihak lain yang turut serta dalam menyeimbangkan kekuatan negara dimana LSM menjadi kekuatan tersendiri bagi masyarakat yang termarjinalkan agar dapat memperoleh hakhak mereka dimana salah satu contoh masyarakat yang termarjinalkan adalah TKI dan keluarganya. Disinilah peran LSM yang menyatakan diri sebagai pembela buruh migran (TKI) mempuyai posisi tersendiri disamping tugas pokok dan fungsi yang dilaksakan oleh pemerintah. (Setyoningsih, Fitriyah, \& Hermini, 2013, p. 11)

Pada umumnya lembaga swadaya masyarakat adalah sebuah organisasi yang didirikan baik secara perorangan maupun secara kelompok dimana organisasi tersebut tidak berorientasi pada hasil atau laba melainkan karena adanya tujuan tertentu di dalam masyarakat. Lembaga swadaya masyarakat ( L S M ) merupakan pengembangan dari sebuah Organisasi Non Pemerintah (ONP) atau juga disebut sebagai lembaga non-government organization (NGO). Jadi, sebuah Lembaga swadaya masyarakat merupakan sebuah organisasi di luar pemerintah, di luar birokrasi, tujuannya bisa membantu kinerja pemerintah bahkan justru ikut mengawasi jalannya pemerintahan agar tidak menjadi penyalahgunaan wewenang. Secara umum pengertian lembaga swadaya masyarakat (LSM) merupakan semua organisasi yang tidak terikat dengan pemerintah dan birokrasi. Sebuah organisasi dapat dikatakan masuk dalam lembaga swadaya masyarakat apabila memiliki beberapa ciri berikut ini: (Sari, 2015)

a. Organisasi tersebut bukan bagian dari pemerintah maupun birokrasi, pendanaannya juga tidak terkait dengan pemerintahan.

b. Organisasi tersebut dalam mencapai tujuannya tidak berorientasi pada laba atau profit belaka melainkan karena adanya tujuan tertentu yang berguna bagi masyarakat pada umumnya,

c.Kegiatan yang dilakukan oleh organisasi tersebut sangat menguntungkan bagi masyarakat umum tidak hanya menguntungkan bagi para anggotanya atau pada profesi tertentu saja.

Lembaga swadaya masyarakat (LSM) akan dapat mencapai tujuannya dengan baik jika mampu menjalankan fungsinya dengan baik dimana fungsi dari Lembaga Swadaya Masyarakat di Indonesia adalah sebagai berikut: (Sari, 2015)

a. Sebagai wadah organisasi yang menampung, memproses, mengelola dan melaksanakan semua aspirasi masyarakat dalam bidang pembangunan terutama pada bagian yang kerap kali tidak diperhatikan oleh pemerintah.

b. Senantiasa ikut menumbuhkembangkan jiwa dan semangat serta memberdayakan masyarakat dalam bidang pembangunan, ini merupakan salah satu fungsi utama dari pembentukan lembaga swadaya masyarakat itu sendiri.

c. Ikut melaksanakan, mengawasi, memotivasi dan merancang proses dan hasil pembangunan secara berkesinambungan tidak hanya pada saat itu juga. Dalam hal ini LSM harus memberikan penyuluhan langsung kepada masyarakat untuk ikut berperan aktif dalam pembangunan.

d. LSM juga harus ikut aktif dalam memelihara dan menciptakan suasana yang kondusif di dalam kehidupan masyarakat bukan sebaliknya justru membuat keadaan menjadi semakin kacau dengan adanya isu-isu palsu yang meresahkan masyarakat.

e. Lembaga swadaya masyarakat sebagai wadah penyalur aspirasi atas hak dan kewajiban warga negara dari masyarakat sesuai dengan tujuan yang telah ditetapkan oleh masing-masing Lembaga swadaya masyarakat.

f. Lembaga swadaya masyarakat juga harus ikut menggali dan mengembangkan segala potensi yang dimiliki oleh anggotanya sehingga dapat mewujudkan tujuan yang telah ditetapkan bersama. Dalam hal ini sangatlah penting karena jika anggota dalam lembaga swadaya masyarakat tidak memiliki potensi sesuai dengan tujuan yang telah ditetapkan akan 
menjadikan LSM seperti halnya mayat hidup, yang ada keberadaannya namun tidak memiliki nyawa di dalamnya.

g. Lembaga swadaya masyarakat sebagai wadah yang ikut aktif dalam perannya mensukseskan pembangunan bangsa dan negara. Serta dalam hal ini ikut menjaga kedaulatan negara serta menjaga ketertiban sosial.

h. Sebagai salah satu cara bagi masyarakat untuk memberikan asiprasinya, kemudian aspirasi ini ditampung oleh lembaga swadaya masyarakat sesuai dengan tujuan LSM itu sendiri dan kemudian akan disalurkan kepada lembaga politik yang bersangkutan guna mencapai keseimbangan komunikasi yang baik antara masyarakat dan pemerintahan seperti politik luar negeri Indonsia.

\section{State Of The Art}

Untuk bisa mengidentifikasi unsur kebaruan (state of the art) dari penelitian ini maka perlu sekali untuk menelaah lebih dulu artikel atau hasil penelitian terdahulu yang tentunya juga membahas tentang perlindungan serta pendampingan Tenga Kerja Indonesia (TKI). Dari data literatur yang diperoleh, terdapat beberapa artikel atau penelitian yang membahas tentang perlindungan serta pendampingan TKI Indonesia. Artikel atau penelitian tersebut anatar lain sebagai berikut:

a. Andreas Afrindo. "Strategi Advokasi Berjejaring Terhadap Tenaga Kerja Indonesia Oleh Serikat Buruh Migran Indonesia (SBMI) Malang”. Dalam penelitian ini peneliti melihat strategi advokasi berjenjang yang dilakukan oleh Serikat Buruh Migran Indonesia (SBMI) kota Malang. Strategi yang ditawarkan ini terdiri dari strategi legal standing dan strategi negosiasi, tetapi strategi yang diterapkan oleh SBMI ini ternyata mengalami kegagalan dikarenakan faktor dari keluarga TKI yang didampingi tidak terlalu kooperatif terhadap proses yang dilaksanakan. (Afrindo, 2014) Penelitian yang dilakukan oleh Andreas Afrindo ini tidak membahas lebih jauh bagaimana pola atau model pendampingan jejaring ini sehingga tidak diketahui model pasti yang diterapkan sehingga sangat sulit mengidentifikasi penyebab kegagalan model tersebut

b. $\quad$ Nurul Hidayatul Fitriyani. "Relasi Kuasa dalam Pengelolaan Remitan TKI Di Kecamatan Jambon Kabupaten Ponorogo (Studi Tentang Perubahan Pengelolaan Remitan TKI ke Sektor Jasa di Kecamatan Jambon Kabupaten Ponorogo)." Tulisan ini membahas tentang relasi kuasa dalam pengelolaan Remitan (pendapatan yang dihasilkan oleh TKI) di Kecamatan Jambon. Fokus kajian dalam tulisan ini lebih kepada faktor ekonomi yang mengiringi banyaknya TKI yang berasal dari suatu daerah. Selain itu juga disebutkan bahwa ada fungsi LSM yang ikut mendampingi proses pengelolaan remitan berarti LSM dalam tulisan ini berada dalam tingkatan fungsi pengawasan. (Fitriyani, 2014) Didalam tulisan ini membahas lebih jauh tentang LSM dalam fungsinya sebagai pengawas pengelolaan remitan ke sektor jasa dan tidak membahas lebih jauh tetang pendampingan bagi TKI yang bermasalah di luar negeri. Dengan kata lain bahwa artikel ini hanya fokus pada pendampingan TKI pasca kepulangannya kedalam negeri sehingga menjadi berdaya.

c. Endang Setyoningsih, Fitriyah dan Hermini. Peran LSM Migrant CARE dalam Membantu TKI Bermasalah di Arab Saudi Tahun 2009 dan 2010”. Fokus kajian dalam tulisan ini adalah peran LSM Migran Care dalam menyelesaikan permasalahan para TKI yang bermasalah di Negara Arab Saudi. Selain itu, dalam tulisan ini juga menjelaskan tentang langkah-langkah advokasi yang dilakukan oleh LSM Migran Care selama penyelesaian masalah TKI. (Setyoningsih, Fitriyah, \& Hermini, 2013) Penelitian Endang Setyoningsih ini membahas lebih jauh tentang pendampingan TKI bermasalah yang diambil sample yaitu TKI yang bekerja di Arab Saudi tetapi langkah advokasi dalam penelitian ini dijelaskan bahwa model legal formal karena pendampingan hanya murni diranah hukum dan tidak memasukkan aspek pendampingan secara personal.

d. Dadi Arja Kusuma "Kebijakan 
Pemerintah Provinsi Nusa Tenggara Barat (NTB) Dalam Penempatan dan Perlindungan TKI”. Dalam tulisan ini Dadi Arjuna membahas tentang kebijakan pemerintah dalam tujuannya untuk memberikan perlindungan bagi TKI di Provinsi Nusa Tenggara Barat (NTB). Kebijakan yang diambil oleh pemerintah Provinsi NTB untuk melindungi TKI adalah dalam bentuk pembentukan Peraturan Gubernur atau bisa dibilang lebih kepada pendekatan yuridis. (KUSUMA, 2014) Penelitian dengan judul diatas membahas bagaimana pemerintah memberikan pendampingan serta perlindungan melalui kebijakan yang diambil yaitu salah satunya dengan membuat Peraturan Gubernur atau bisa dibilang pmelakukan pendekatan secara yuridis.

e. Marhendra Handoko "Advokasi Terhadap Permasalahan Penempatan Dan Perlindungan TKI Di Luar Negeri”. Artikel ilmiah ini memandang Tenaga Kerja Indonesia (TKI) yang harus diberi perlindungan hukum oleh Negara dan dijamin keselamatannya dari berbagai tindak kejahatan yang mengancam keberlangsungan hidup dan nyawanya kerap kali hanya impian belaka, ibarat republik mimpi yang menjanjikan hal tersebut namun pada kenyataannya sebaliknya, bahkan yang didapat hanya kepahitan ditengah-tengah keuntungan belimpah atau devisa negara yang tinggi. Kelalaian Negara dalam memberikan perlindungan kepada TKI menurut penulis Mahendra merupakan suatu kesalahan besar dan harus mendapatkan kritik tajam sehingga dengan begitu akan menciptakan perbaikan. (Handoko, 2010) Fokus dari tulisan ini adalah perlindungan terhadap TKI yang lebih condong menganalisis kebijakan pemerintah atau bisa dikatan menggunakan pendekatan legal formal dan tidak menyentuh sama sekali pendekatan personal.

Dari literatur direview diatas dapat disimpulkan bahwa sebagian besar dari literatur tersebut hanya membahas tentang pendampingan yang bersifat yuridis atau legal formal dan belum ada yang membahas atau melihat lebih jauh tentang pola/model dari pendampingan LSM terhadap TKI bermasalah sedangkan pola atau model yang sesuai untuk menangani masalah TKI ini akan berdampak pada keberhasilan penyelesaian kasus TKI. Dengan melihat lebih jauh aspek personal dan tidak juga mengesampingkan aspek legal formal maka perlu sekali menelaah kasus TKI tidak hanya dari sisi hukum tetapi perlu juga dilihat dari dari aspek sosiologis.

\section{Permasalahan}

Dengan melihat latar belakang yang sudah disampaikan di dalam bab sebelumnya, maka sangat menarik sekali jika melihat lebih jauh tentang model advokasi yng dilakukan oleh Lembaga Swadaya Masyarakat (LSM) JKPS Cahaya kepada Tenaga Kerja Indonesia (TKI) asal Kabupaten Ponorogo serta seberapa efektif advokasi yang dilaksanakan dalam mengatasi permasalahan TKI.

\section{Metode Penelitian}

Jenis penelitian yang akan dipakai dalam penelitian ini adalah kualitatif, dimana penelitian kualitatif menekankan analisisnya pada proses penyimpulan deduktif dan induktif serta pada analisis terhadap dinamika hubungan antar fenomena yang diamati, yaitu dengan menggunakan logika ilmiah. Untuk penggalian data, peneliti menggunakan dua jenis data yaitu data primer dan data sekunder. Alasan peneliti menggunakan data sekunder adalah sebagai pendukung atau penguat dari data primer. Metode Penelitian yang akan digunakan dalam penelitian ini adalah deskriptif. Dimana metode deskriptif ini melakukan analisis hanya sampai diskripsi, yaitu menganalisis dan menyajikan fakta secara sistemik, sehingga dapat lebih mudah untuk difahami dan disimpulkan.

\section{B. Hasil dan Pembahasan \\ 1. Deskripsi LSM JKPS Cahaya}

Jaringan Kerja Perlindungan Sosial TKI dan Anggota Keluarganya "Cahaya" (JKPS CAHAYA) berdiri selama 20 tahun sejak 15 September 1995 tepatnya di dukuh Ngadirogo Wetan, Desa Blembem, Kecamatan Jambon, Kabupaten Ponorogo. 
Sampai saat ini, kesekretariatan dari LSM JKPS masih berada di Dukuh Ngadirogo Wetan, Desa Blembem, Kecamatan Jambon, Kabupaten Ponorogo. Sampai saat ini, ketua dari LSM JKPS CAHAYA masih dipegang oleh Bapak Danuhardi.

Azas organisasi LSM JKPS ini adalah gotong royong dimana kepada setiap anggota di LSM ini saling membantu satu sama lain dalam hal pendanaan serta dalam menyelesaikan permasalahan TKI yang di tangani. Secara struktural, organiasasi ini murni bersifat sosial, non-partisipan dan independen sehingga bisa leluasa dalam menangani setiap permasalahan TKI bermasalah karena tidak adanya keberpihakan kepada siapapun. Bagi para anggota LSM JKPS CAHAYA, organisasi ini berfungsi sebagai wadah berkumpul, alat perjuangan, pembelaan dan perlindungan kepada para buruh migran (TKI) sebagai penyuumbang devisa bagi negara ini dan sebagai pembangun sektor ekonomi bagi Kabupaten Ponorogo.

Adapun tujuan dari organisasi LSM JKPS CAHAYA ini adalah untuk memberdayakan TKI dan anggota keluarganya serta memberikan perlindungan dan pembelaan TKI dan anggota keluarganya. Dalam pencapaian tujuan organisasi, LSM JKPS CAHAYA melakukan usaha-usaha sebagai berikut:
a. Melakukan pemberdayaan terhadap
TKI dan anggota keluarganya
b. Advokasi kebijakan dan advokasi kasus
TKI dan anggota keluarganya
c. Pendidikan masyarakat
d. Promosi Konvensi Hak Anak (KHA)
Dalam mencapai tujuan diatas, LSM

JKPS CAHAYA melakukan kegiatankegiatan baik ditigkat Pusat, Kecamatan maupaun Desa yang berupa :
a. Pelatihan-pelatihan baik kepada TKI purna maupun keluarga TKI.

b. Kampanye terhadap pentingnya manajemen keluarga dan perlindungan TKI saat di penampungan, pemberangkatan dan kepulangan. Selain itu, LSM JKPS CAHAYA juga sering mengkampanyekan tentang hakhak anak yang secara khusus kepada hak anak TKI.

c. Sosialisasi tentang manajemen ekonomi keluarga, perlindungan TKI, dan penanganan TKI yang bermasalah baik yang di luar negeri maupun di dalam negeri.

\section{Permasalahan TKI Ponorogo}

LSM JKPS CAHAYA mulai melakukan pendampingan terhadap TKI bermasalah sejak didirikan yaitu tahun 1996 dengan jumlah TKI bermasalah yang didampingi sejak berdiri mencapai jumlah ratusan. Menurut Bapak Danuhardi, permasalahan yang sering terjadi terhadap TKI bermacammacam, tetapi bisa dikelompokkan menjadi tiga bagian besar yaitu permasalahan di keberangkatan, permasalahan di tempat kerja dan permasalahan saat kepulangan. Seperti contoh kecil adalah gaji yang tidak dibayarkan, PHK oleh majikan di tempat kerja dan putusnya informasi dengan keluarga yang di tanah air.

Jika kita melihat lebih jauh lagi terkait dengan TKI yang bermasalah berdasarkan jenis kelamin, menurut Bapak Danuhardi TKI perempuanlah yang sering mengalami permasalahan baik waktu keberangkatan, ditempat kerja atau saat kepulangan. Sedangkan jika kita lihat TKI bermasalah berdasarkan negara tujuan, untuk khusus kasus di Kabupaten Ponorogo, negara tujuan TKI yang banyak mengalami masalah adalah TKI yang berasal dari Malaysia, Arab Saudi dan Hongkong. Jika di lihat lebih jauh tentang permasalahan yang sering dialami TKI saat keberangkatan, bekerja, dan saat kepulangan menurut data yang di himpun dari LSM JKPS CAHAYA adalah sebagai berikut:

a. Masalah yang dialami TKI sebelum keberangkatan:

- Perekrutan secara ilegal

- Pelmasuan dokumen

- Pemalsuan identias pada dokumen

- Pungutan liar saat pengurusan dokumen di Desa

- Pungutan biaya pemberangkatan oleh PPTKIS yang terlalu besar

- Terjebak rentenir saat sebelum berangkat 
- Diperjualbelikan diantara calo dan PPTKIS

- Penyekapan di penampungan karena dijadikan stok manusia

- Pemerasan oleh PPTKIS ketika membatalkan kontrak kerja

- Kondisi penampungan yang tidak memadai

- Selama di penampungan, dipekerjakan di rumah pemilik PPTKIS dan tidak dibayar dengan alasan PKL

- Selama dipenampungan sulit berkomunikasi dengan keluarga

- Terjadinya kekerasan psikis dan intimidasi saat di penampugan

- Kekerasan fisik saat di penampungan

- Pelecehan sexual saat di penampungan

- TKI terlalu lama menunggu jib rder di penampungan

- Tidak diberikan pelatihan saat di penampungan

- Pelatihan tidak dilakukan dengan professional dan sekedar formalitas

- TKI tidak diasuransikan

- Penandatanganan surat Perjanjian Kerja dalam situasi tergesa-gesa sehingga CTKI tidak bisa membaca keseluruhan yang mengakibatkan kerugian pada pihak TKI

- Penelantaran kasus ketika diadukan kepada pihak yang berwajib (kepolisian).

b. Masalah yang dialami TKI pada saat bekerja:

- Dijebak untuk dijadikan pelacuran didaerah transit

- Diperjualbelikan antar agensi diluar negeri

- Jenis pekerjaan tidak sesuai dengan Perjanjian Kerja (PK)

- Jam kerja melampaui batas dan tanpa uang lembur

- Semua dokumen dipegang oleh majikan tempat bekerja

- Akomodasi dan makan di tempat kerja tidak memadai

- Dilarang beribadah oleh majikan

- Pemotongan gaji oleh agensi yang nominalnya terlalu besar

- Gaji tidak dibayarkan
- Memperpanjang kontrak tanpa ijin keluarga

- Pungutan yang tinggi saat perpanjangan kontrak

- Disiksa, dianiaya dan diperkosa oleh majikan ataupun pegawai agensi

- Dipenjara oleh majikan atau agensi

- Diberhentikan secara sepihak dan dipulangkan tanpa menerima hakhaknya

- Penipuan dengan modus medical yang direkayasa dan akhirnya dipulangkan karena dianggap tidak sehat

- Dideportasi oleh negara tujuan dan ditangkap oleh calo dan kemudian diberangkatkan kembali tanpa sepengetahuan keluarga

- Ketidak pedulian Staf KBRI kepada permaslahan TKI

- Terbatasnya akses informasi yang bisa dilakukan oleh keluarga kepada TKI

- Sebelum kepulangan dipaksa menandatangani surat ang kemudia diketahui isinya adalah pernyataan telah menerima gaji padahal gaji tidak diberikan.

c. Masalah yang dialami TKI saat kepulangan:

- Tidak terpenuhinya hak-hak asuransi, retribusi pajak, tabungan dan barangbarang yang tertinggal di luar negeri

- Perlakuan diskriminatif di bandara

- Harus membayar sendiri ongkos pesawat/kapal ketika pulang dari luar negeri

- Diperas atau terjadi pungutan liar yang dilakukan oleh oknum bandara dengan berbagai dalih

- Barang banyak yang hilang di bandara dengan dalih uang pungutan

- Dipaksa membeli sesuatu di bandara dengan harga yang sangat mahal

- Perampasan barang-barang saat perjalanan pulang

- Masuk perangkap calo dan dijual lagi keluar negeri

- Sopir pengantar TKI meminta bayaran lebih

- TKI pulang dalam keadaan hamil sehingga status kewarganegaraan yang 
tidak jelas bagi anak yang dilahirkan

- Penahanan dokumen oleh PPTKIS dan calo.

\section{Gerakan LSM JKPS Cahaya}

Sejak berdiri tahun 1996, LSM JKPS CAHAYA telah diklerasikan menjadi gerakan sosial yang berarti semua visi misi dan tujuan demi kepentingan sosial serta bukan profit oriented. Gerakan yang dilakukan oleh LSM JKPS murni gerakan sosial (relawan) tanpa meminta uang imbalan atas keberhasilan permasalahan yang sudah diatasi. Gerakan sosial ini menjadi tujuan utama organisasi ini karena LSM JKPS juga terdiri dari para TKI Purna, keluarga TKI serta penggiat sosial yang memiliki satu perasaan sama terhadap TKI.

Selain melaksanakan kegiatan advokasi terhadap TKI bermasalah dan keluarga TKI, LSM JKPS CAHAYA juga masih memiliki program kerja lain yang masih dalam lingkul sosial, yaitu:

a. Pelatihan pendamping TKI bermasalah

b. Pelatihan HIV/AIDS (kerjasama dengan Dinas Kesehatan Kabupaten Ponorogo dan Rumah Sakit Giya Waluyo)

c. Pelatihan Kewirausahaan yang b e $\mathrm{k}$ e $\mathrm{r}$ a $\mathrm{s}$ a $\mathrm{m}$ a $\mathrm{d}$ e $\mathrm{n}$ a $\mathrm{n}$ DINSOSNAKERTRANS Provinsi J a w a $\mathrm{T} \mathrm{i} \mathrm{m} \mathrm{u} \mathrm{r} \mathrm{d} \mathrm{a} n$ DINSOSNAKERTRANS Kabupaten Ponorogo.

d. Penyuluhan HIV/AIDS dengan bekerjasama dengan A ILO (Internasional)

e. Advokasi kegijakan terkait dengan undang-undang perlindungan TKI dan PERDATKI

f. Bina Keluarga TKI yang meliputi kesehatan keluarga dan kesejahteraan keluarga (SAMAWA)

g. Pendampingan TKI bermasalah yang b e $\mathrm{k}$ e $\mathrm{r}$ a s a m a d e $\mathrm{n}$ g a $n$ DINSOSNAKERTRANS

Dengan tidak hanya melakukan program advokasi terhadap TKI bermasalah, maka LSM JKPS telah membantu para TKI purna untuk bisa mandiri hingga mampu membangun usaha di Desanya masingmasing. Harapan lebih jauh dari pemberdayaan TKI purna ini adalah agar para TKI setelah pulang ke tanah air bisa membangun usaha dan tidak berkeinginan kembali ke kuar negeri. Selain itu, dengan berdayanya TKI purna maka mampu meningkatkan perekonomian Desa tempat TKI tersebut berasal.

\section{Model Pendampingan LSM JKPS Cahaya}

Sejak tahun 1996, LSM JKPS CAHAYA sudah mendampingi TKI bermasalah asal Kabupaten Ponorogo mencapai ratusan, dari jumlah tersebut hampir $90 \%$ terselesaikan baik permasalahan saat keberangkatan, ditempat kerja ataupun saat kepulangan TKI. Sesuai dengan Pasal 2 dalam AD/ART LSM JKPS CAHAYA, bentuk organisasi ini adalah Jaringan Kerja Antar Kelompok Tingkat Desa/Kelurahan dan Kelompok Sosial. Jaringan kerja yang dimaksud adalah, terdapat kelompok-kelompok kecil yang dibangun oleh LSM JKPS ini di tingkat Kecamatan dan tingkat Desa dengan tujuan untuk mempermudah LSM ini dalam memberikan asistensi kepada TKI bermasalah di tingkat yang paling bawah. Jaringan organisasi ini bukan hanya berada di Indonesia saja tetapi juga terdapat kelompokkelompok jaringan LSM JKPS di luar negeri.

Prosentase dari jumlah penanganan kasus-kasus TKI ini menggambarkan LSM JKPS CAHAYA telah berhasil dalam melakukan pendampingan TKI bermasalah baik saat keberangkatan, ditempat kerja ataupun saat kepulangan. Keberhasilan yang dicapai oleh LSM JKPS ini tidak lepas dari strategi pendampingan yang digunakan sehingga prosentase keberhasilan menjadi sangat tinggi. Adapun pola pendampingan yang dilakukan oleh JKPS dalam menangani permasalahan TKI yaitu menggunakan pola "pendampingan berjenjang", dimana setiap kasus TKI di suatu Desa tertentu akan terlebih dahulu ditangani oleh LSM JKPS tingkat Desa tersebut dengan tujuan krn dianggap perwakilan LSM di Desa tersebut akan lebih tahu pasti kultur budaya maupun aspek 
sosiologis dari daerah tersebut. Jika LSM JKPS tingkat Desa tidak bisa menyelesaikan permasalahan TKI bermasalah tersebut, maka akan ditangani oleh tingkat yang lebih tinggi yaitu di tingkat Kecamatan. Pada saat di tingkat kecamatan sudah terselesaikan masalahnya, maka kasus akan ditutup, tetapi jika tingkat Kecamatan juga tidak bisa menyelesaikan permasalahannya maka permasalahan TKI ini akan ditangani oleh LSM JKPS di tingkat Pusat. Jika kita gambarkan struktur penanganan TKI bermasalah di LSM JKPS CAHAYA ini adalah sebagai berikut :

Tabel.

Pola Pendampingan LSM JKPS CAHAYA

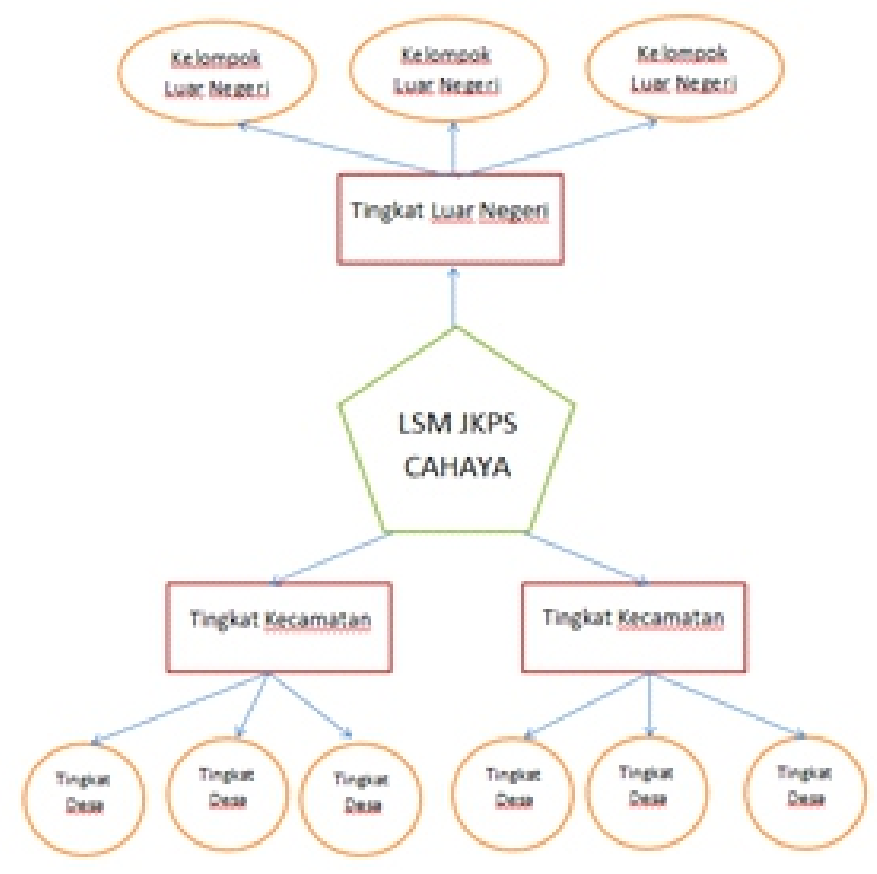

Setelah kita lihat model pendampingan yang dilakukan oleh LSM JKPS CAHAYA, maka selanjutnya kita bisa membandingkan dengan model pendampingan yang dilakukan oleh Pemerintah terutamanya Pemerintah Kabupaten Ponorogo. Model pendampingan yang dilakukan oleh Pemerintah Kabupaten Ponorogo adalah dengan melakukan pengawalan serta koordinasi dengan Dinas-
Dinas terkait. Dengan kata lain, model pendekatan yang dilakukan oleh pemerintah Kabupaten Ponorogo ini lebih condong kepada pendekatan institusional birokrasi dan tidak secara sosiologis kultural. Pendekatan struktural birokrasi ini pada kenyataanya akan sangat kaku jika diterapkan saat penanganan kasus TKI yang bermasalah karena tidak terdapatnya kedekatan secara personal antara pendamping dengan TKI bermasalah.

\section{Simpulan}

Berdasarkan analisis data yang telah dipaparkan diatas maka dapat diambil kesimpilan bahwa:

Model advokasi yang diterakan oleh LSM JKPS Cahaya memiliki tingkat keberhasilan yang tinggi dimana dari jumlah aduan yang mencapai ratusan yang masuk ke LSM JKPS Cahaya, hampir 90\% terselesaikan baik permasalahan saat keberangkatan, ditempat kerja ataupun saat kepulangan TKI. Sesuai dengan Pasal 2 dalam AD/ART LSM JKPS CAHAYA, bentuk organisasi ini adalah Jaringan Kerja A n t a r Kelom pok Tingkat Desa/Kelurahan dan Kelompok Sosial. Jaringan kerja yang dimaksud adalah, terdapat kelompok-kelompok kecil yang dibangun oleh LSM JKPS ini di tingkat Kecamatan dan tingkat Desa dengan tujuan untuk mempermudah LSM ini dalam memberikan asistensi kepada TKI bermasalah di tingkat yang paling bawah. Jaringan organisasi ini bukan hanya berada di Indonesia saja tetapi juga terdapat kelompokkelompok jaringan LSM JKPS di luar negeri.

Adapun pola pendampingan yang dilakukan oleh JKPS dalam menangani permasalahan TKI yaitu menggunakan pola "pendampingan berjenjang", dimana setiap kasus TKI di suatu Desa tertentu akan terlebih dahulu ditangani oleh LSM JKPS tingkat Desa tersebut dengan tujuan krn dianggap perwakilan LSM di Desa tersebut akan lebih tahu pasti kultur budaya maupun aspek sosiologis dari daerah tersebut. Jika 
LSM JKPS tingkat Desa tidak bisa menyelesaikan permasalahan TKI bermasalah tersebut, maka akan ditangani oleh tingkat yang lebih tinggi yaitu di tingkat Kecamatan. Pada saat di tingkat kecamatan sudah terselesaikan masalahnya, maka kasus akan ditutup, tetapi jika tingkat Kecamatan juga tidak bisa menyelesaikan permasalahannya maka permasalahan TKI ini akan ditangani oleh LSM JKPS di tingkat Pusat.

Jika dibandingkan dengan model pendampingan yang dilakukan oleh Pemerintah Kabupaten Ponorogo yaitu dengan melakukan pengawalan serta koordinasi dengan Dinas-Dinas terkait, maka dengan kata lain model pendekatan struktural birokrasi ini pada kenyataanya akan sangat kaku jika diterapkan saat penanganan kasus TKI yang bermasalah karena tidak terdapatnya kedekatan secara personal antara pendamping dengan TKI bermasalah. Dengan demikian, pola "pendampingan berjenjang" yang diterapkan oleh LSM JKPS CAHAYA akan sangat efektif jika diterapkan untuk melakukan advokasi kepada TKI bermasalah.

\section{DAFTAR PUSTAKA}

Afrindo, A. (2014). Strategi Advokasi Berjenjang Terhdap Tenaga Kerja Indonesia oleh Serikat Buruh Migran Indonesai (SBMI) Malang. Jurnal Ilmu Pemerintahan Universitas Brawijaya Malang, 1-21.

BNP2TKI, P. (2015). Data Penempatan dan Perlindungan Tenaga Kerja Indonesia Tahun 2015. Surabaya: PUSLITFO BNP2TKI.Fitriyani, N. H. (2014). REL A S K U A S A A L A M PENGELOLAAN REMITAN TKI DI K E C A M A T A N J A M O N KABUPATEN PONOROGO. Jurnal Mahasiswa Sosiologi, 1-14.

Handoko, M. (2010). ADVOKAS I TERHADAP PERMASALAHAN $P$ E $N$ E M P A A N D A N
PERLINDUNGAN TKI DI LUAR NEGERI. Warta Hukum, 1-8.

Hidayah, A. (2011, Juni 23). Realitas Ruyati di Balik Pidato SBY. Retrieved Februari 26, 2016 , from http://internasional.kompas.com: http://internasional.kompas.com/read/ 2011/06/23/02562060/Realitas.Ruyati. di.Balik.Pidato.SBY

JATIM, P. (2004). Peraturan Daerah Propinsi Jawa Timur Nomor 02 Tahun 2004. Jawa Timur: Pemprov JATIM.

KUSUMA, D. A. (2014, oktober 23). KEBIJAKAN PEMERINTAH PROVINSI NUSA TENGGARA B A R A ( N T B ) D A L A M P E N E M P A T A N D A N PERLINDUNGAN TKI. Retrieved Februari 19, 2016 , from h t t p : //fh.un ram.ac.id: ht tp://fh.unram.ac.id/wpcontent/uploads/2014/07/KEBIJAKA N-PEMER INTA H - P R O V IN S I NUSA-TENGGARA-BARAT-NTBDALAM-PENEMPATAN - DAN PERLINDUNGAN-TKI.pdf

Meleong, J. L. (2002). Metodologi Penelitian Kualitatif. Bandung: Remaja Rosdakarya.

Narbuko, C., \& Achmadi, A. (2003). Metode Penelitian Kualitatif (ed2). Bandung: PT. Remaja Rosda Karya.

RI. (2004). Undang-Undang Republik Indonesia Nomor 39 Tahun 2004 Tentang Penempatan dan Perlindungan Tenaga Kerja Indonesia di Luar Negeri. Indonesia: Republik Indonesia.

Sari, M. (2015, November 25). 8 Fungsi Lembaga Swadaya Masyarakat (LSM). Retrieved Februari 20, 2016, from http://guruppkn.com: http://guruppkn.com/fungsi-lembagaswadaya-masyarakat

Setyoningsih, E., Fitriyah, \& Hermini. (2013). Peran LSM Migrant CARE dalam Membantu TKI Bermasalah. Journal Of Politic And Government Studies, 261-270.

Sudarmawan. (2014, Februari 28). JKPS Cahaya Ponorogo Bakal Perjuangan 
Masalah - Masalah Hukum, Jilid 46 No. 1, Januari 2017, Halaman 30-40

Nasib Anis Andriani. Retrieved

F e b r u a i 19,206 , from http://surabaya.tribunnews.com: http://surabaya.tribunnews.com/2014/ 02/28/jkps-cahaya-ponorogo-bakalperjuangan-nasib-anis-andriani.

Sujarwoko, D. H. (2012, Maret 26). TKI Ponorogo Tewas Akibat Hirup Gas Beracun. Retrieved Februari 19, 2016, from http://www.antarajatim.com: http:/www.antarajatim.com/lihat/berit a/84957/tki-ponorogo-tewas-akibathirup-gas-beracun. 